\title{
SCREENING OF LACCASE PRODUCER FROM SOIL AND ITS APPLICATIONS
}

\author{
Rutuja S. Palaskar*, Savita A. Kate, Mayuri S. Khandagale, Swapnil B. Namekar, \\ Satyajeet B. Aher, Abhijit R. Nale, Anjali J. Tandale \\ Department of Biotechnology, Shivchhatrapati College, Aurangabad, Maharashtra, India \\ *Corresponding author:savitaakate@gmail.com,rutujapalaskar@gmail.com
}

\begin{abstract}
In present work, twenty-eight bacteria and thirty fungi were isolated from soil on Luria Bertani (LB) Agar at $37^{\circ} \mathrm{Cin} 2-3$ days, Potato Dextrose Agar (PDA) at $28 \pm 2{ }^{\circ}$ Cafter 3 days of incubation respectively. From bacterial isolates, three bacteria and three fungi showed intense development of brown color using 1\%Tannic acid as a substrate in 3-4 days at $37^{\circ} \mathrm{Cwhich}$ indicates they were laccase producers and are identified as Pseudomonas aeruginosa, Erwinia chrysantemi, Klebshiella oxytoca, Cladosporium spp. and two Aspergillius spp. Crude laccase of Klebshiella oxytoca was extracted by centrifugation then partially purified using $40 \%$ \& $70 \%$ ammonium sulphate precipitation. Partially purified laccase expressed highest activity $980 \mathrm{U} / \mathrm{ml}$ at $\mathrm{pH} 7.5 \& 30^{\circ} \mathrm{Cafter} 30 \mathrm{~min}$ of incubation using $1 \%$ tannic acid. Immobilization of partially purified laccase was done by entrapment method using sodium alginate. Partially purified and immobilized laccase showed $97 \%$ of crystal violet \& 94\% neutral red dye degradation in 3 days of incubation as well as meat tenderization. It has antibacterial activity against S. aureus, S.typhi, and Agrobacterium tumifaciens and showed zone of inhibition ranging from $17 \mathrm{~mm}-20 \mathrm{~mm}$. Immobilized laccase also synthesized silver nanoparticle at $75^{\circ} \mathrm{Cin} 3-4 \mathrm{hrs}$. Laccase from Klebshiella oxytoca in our work have wide applications and can be used in bioremediation.
\end{abstract}

Keywords: Laccase, Tannic acid, Dyes, Meat tenderization, Antibacterial activity, Silver-nanoparticle.

\section{INTRODUCTION}

Laccases (E.C.1.10.3.2, p-diphenol: dioxygen oxidoreductase) are a group of multi-copper containing enzymes that catalyze one-electron oxidation of phenolic compounds with concomitant reduction of oxygen to water [1]. They were first discovered in the lacquer of the Japanese tree Toxicodendron vernicifluum (formerly Rhus venicifera), from which the name laccase was taken. Later, it was shown that laccase enzymes were widely distributed in nature. The first bacterial laccase was found in the plant-root-associated bacterium, Azospirillum lipoferum. [2].

Laccase is one of the most actively investigated enzymes for the remediation of environmental pollutants. Laccase (p-diphenol: oxygen oxidoreductase), the most important number of lignolytic system, is multi copper enzyme belonging to the group of blue-copper proteins. Laccases are secreted by the family of fungi known as "white rots"[3]. Laccase is widely distributed in higher plants and fungi and has been found also in insects and bacteria. Recently a novel polyphenol oxidase with laccase like activity was mined from a metagenome expression library from bovine rumen Microflora [4].
Laccases find wide commercial applications within food industry, pulp and paper industries, textile industry, synthetic chemistry, cosmetics, soil bioremediation and biodegradation of environmental phenolic pollutants and removal of endocrine disruptors [1].

Laccase is generally found in higher plants and fungi but, recently it was found in some bacteria such as S. lavendulae, S. cyaneus, and Marinomonas mediterranea. In fungi, laccases appear more than the higher plants. Basidiomycetes such as Phanerochaete chrysosporium, Theiophora terrestris, and Lenzites, betulina and white-rot fungi such as Phlebia radiate, Pleurotusostreatus and Trametes versicolour also produce laccase. Many Trichoderma species such as $T$. atroviride, $T$. harzianum, and $T$. longibrachiatum are the sources of laccases. Laccase from the Monocillium indicum was the first laccase to be characterized from Ascomycetes which shows peroxidase activity. Pycnoporus cinnabarin produces laccase as ligninolytic enzyme while Pycnoporus sanguineus produces laccase as phenol oxidase. In plants, laccase plays a role in lignifications whereas in fungi it has been implicated in delignification, sporulation, pigment production, fruiting body formation, and plant pathogenesis [5]. 
The aim of present study is to isolate laccase producer from soil, study their optimization parameters and useful applications for society.

\section{MATERIAL AND METHODS}

\subsection{Isolation, Screening and identification of laccase producing bacteria and fungi}

Five soil samples were collected from garden area, industrial area, bio fertilizer soil, coconut root soil \& lake area of the Aurangabad, Maharashtra, India. Initial isolation of bacteria and fungi were done from soil samples on nutrient agar and potato dextrose agar (PDA) by employing standard serial dilution method. The laccase producing fungi and bacteria were screened based on the growth on PDA media (at $30^{\circ} \mathrm{C}$ for $3-4$ days) and Luria Bertani (LB) media (at $37^{\circ} \mathrm{C}$ for $24 \mathrm{hrs}$.) respectively containing tannic acid as a substrate. PDA plates and LB plates were observed for growth and development of brown colored zone in plates containing tannic acid [6]. Most efficient laccase producing bacteria were identified by biochemical and morphological characteristic as prescribed by Bergey's Manual of systematic bacteriology volume-2(1984).

\subsection{Laccase production (Bacteria and Fungi)}

For laccase production, 2\% bacterial inoculum of 0.1 O.D.600nm [7] and 2 discs $6 \mathrm{~mm}$ disc of $48-72 \mathrm{hrs}$ old fungal culture were inoculated into $25 \mathrm{ml}$ of production medium Luria-Bertani (LB broth) \& Potato dextrose broth containing $1 \%(2 \mathrm{mM})$ tannic acid as a substrate at $37^{\circ} \mathrm{C} \& 30^{\circ} \mathrm{C}$ for $2 / 3$ days on a rotary shaker at $100 \mathrm{rpm}$ respectively [8]. Bacterial and fungal cells were removed by centrifugation under cooling condition $\left(4^{\circ} \mathrm{C}\right)$ at 10,000 rpm for 20 minutes and supernatant obtained was used as a crude laccase enzyme, and assay was carried out as per method [6] with some modifications. Tannic acid $(2 \mathrm{mM})$, in phosphate buffer $(\mathrm{pH} 7.0)$ was used as substrate. The reaction mixture contained $3 \mathrm{ml}$ acetate buffer, $1 \mathrm{ml}$ tannic acid and $1 \mathrm{ml}$ crude enzyme and one tube without enzyme as a control were incubated at $37^{\circ} \mathrm{C}$ for $15 \mathrm{~min}$, then absorbance was measured at $450 \mathrm{~nm}$. One unit (U) of laccase was defined as a change in absorbance of $0.001 \mathrm{~min}^{-1}[1]$.

\subsection{Partial purification of laccase}

Most proficient laccase producer bacterial cell free extract after centrifugation was subjected to precipitation by adding solid ammonium sulphate (40\% and $70 \%$ ) at $4^{\circ} \mathrm{C}$ for $24 \mathrm{~h}$. The precipitate obtained was dissolved in minimum amount of phosphate buffer $(\mathrm{pH}$
7.5) dialyzed overnight against the same buffer and then concentrated on sucrose [9]. Laccase activity of each sample was analyzed and further preceeded for optimization.

\subsection{Optimization parameters for laccase activity \\ 2.4.1. Effect of $\mathrm{pH}$, temperature, substrate and incubation period on laccase activity}

To determine the effect of $\mathrm{pH}$, the laccase activity was measured with $2 \mathrm{mM}$ tannic acid as a substrate dissolved in different buffers with varying $\mathrm{pH}$ range ( $\mathrm{pH} 4.5$ to 8). The buffer system used in present work as sodium acetate buffer ( $\mathrm{pH} 4$ to 5 ) phosphate buffer ( $\mathrm{pH} 6$ to 8 ) and effect of temperature was studied at different temperature range $15,30,37,45,55$ and $65^{\circ} \mathrm{C}$ by using $2 \mathrm{mM}$ substrate. Optimum substrate concentration for highest laccase activity was determined in phosphate buffer of $\mathrm{pH} 7.5$ with varying substrate concentration $1 \mathrm{mM}, 2 \mathrm{mM}, 4 \mathrm{mM}, 6 \mathrm{mM}$ and $8 \mathrm{mM}$ tannic acid and effect of incubation period was studied by incubating the sample at different incubation periods from $5 \mathrm{~min}$, $10 \mathrm{~min}, 15 \mathrm{~min}, 20 \mathrm{~min}, 30 \mathrm{~min}, 40 \mathrm{~min}, 50 \mathrm{~min}$. and $60 \mathrm{~min}$ and laccase activity was measured under standard assay condition as per protocol [6].

\subsection{Effect of Metal-ions and Organic solvents}

To determine the effect of metal-ions on laccase activity, the enzyme was incubated in presence of metalions such as $1 \mathrm{mM}$ sodium sulphate, EDTA, Magnesium sulphate, $\mathrm{Mn}_{2} \mathrm{SO}_{4}$, mercuric chloride, copper sulphate, 1\% DMSO, zinc sulphate. Enzyme was removed after $30 \mathrm{~min}$. and optical density was measured at $540 \mathrm{~nm}$ [10]. Laccase activity measured in the absence of any inhibitor or metal ions was taken as $100 \%$ relative activity.

\subsection{Immobilization of laccase}

For immobilization, $500 \mathrm{mg}$ sodium alginate was dissolved in $25 \mathrm{ml}$ hot water and allowed to cool, to it 2 gm. freeze dried laccase was added and homogenized slurry was made. Using dropper slurryd $2 \% \mathrm{CaCl}_{2}$ solution in drop wise manner was added. Beads of sodium alginate entrapped with laccase were formed and allowed to harden in $2 \% \mathrm{CaCl}_{2}$ for $1 \mathrm{hr}$. at $4^{\circ} \mathrm{C}$ [11]. To check laccase activity in immobilized form, beads were removed from $\mathrm{CaCl}_{2}$, washed 3-4 times with distilled water and preceeded for assay. 4-5 beads of immobilized laccase were added in $1 \mathrm{ml}$ phosphate buffer (pH 7.5) and preceeded as described earlier [6]. 


\subsection{Dye Degradation}

The ability of bacterial laccase to degrade dyes was analyzed by adding different concentrations of the laccase such as $0.5 \%, 1 \%$, and $2 \%$ in $0.01 \mathrm{gm} / \mathrm{ml}$ crystal violet, neutral red tubes and incubated at $30^{\circ} \mathrm{C}$. Dyes degradation by laccase was checked by taking O.D. at $540 \mathrm{~nm}$ after incubation periods 1day, 2days and 3days, compared with control (without laccase) [8].

\subsection{Meat tenderization}

\subsubsection{Determination of Water-holding Capacity}

Fresh boneless meat was sliced into several pieces of approximately the same size and weight. The meat was divided into two groups; one group was used for the experiment and the other used as control group. The experiment group consisted of 4 samples and the control group had one sample; C-Control (Sample without laccase), L1 -Sample treated with 1\% laccase, L2-Sample treated with 2\% laccase, L3-Sample treated with 3\% laccase and L4-Sample treated with $4 \%$ laccase. $6 \mathrm{~g}$ samples of meat (treated with control, 1\%, 2\%, 3\% and $4 \%$ of laccase) were stirred for 1 min with $10 \mathrm{ml}$ of $0.6 \mathrm{M}$ sodium chloride $(\mathrm{NaCl})$ solution in a $15 \mathrm{ml}$ centrifuge tube. The tube then was held at $4^{\circ} \mathrm{C}$ for 15 min, stirred again for $1 \mathrm{~min}$ and centrifuged at 10,000 rpm at $4^{\circ} \mathrm{C}$ for $15 \mathrm{~min}$. After centrifugation, the volume of the supernatant was measured and the water-holding capacity of the meat treated with various concentrations of meat was calculated using the formula [12].

WHC $(\%)=$ (Initial volume -Volume of supernatant/ Initial volume) x 100

\subsection{Silver nanoparticles synthesis}

$10 \mathrm{ml}$ of $1 \mathrm{mM}$ of silver nitrate was taken in test tube and 5-6 beads of immobilized laccase were added and incubated at $75^{\circ} \mathrm{C}$ for $2-3 \mathrm{hrs}$ and observed for color change, silver nanoparticles were washed by centrifugation at $10000 \mathrm{rpm}$ for $10 \mathrm{~min}$ at $4^{\circ} \mathrm{C}$ and used further for antibacterial activity [13].

\subsection{Antibacterial activity}

Antibacterial activity of laccase and silver nanoparticles produced by laccase against the pathogenic test organisms like Agrobacterium tumificiens, S. aureus, E. coli, S.typhi was evaluated by agar well diffusion method [14].

\section{RESULT AND DISCUSSION}

\subsection{Isolation and identification of bacteria $\&$ fungi from soil samples}

Bacteria (28) and 30 fungi were isolated on Luria Bertani agar and potato dextrose agar, respectively after
3-5 days of incubation from the soil samples collected from various different garden soils of Aurangabad, (Maharashtra). Out of the isolated bacteria and fungi, twenty-six bacteria and thirteen fungi were able to oxidize tannic acid present in the LB, PD broth medium respectively, development of brown colored surroundding to colonies, indicates laccase producers (Fig 1). The most efficient laccase producing bacteria (3) and fungi (3) were further identified as per Bergey's Manual of systematic bacteriology volume-2(1984), VITEC, ABIS software bacteria were found to be Erwinia chrysanthemi, Pseudomonas aeruginosa and Klebsiella Oxytoca (Fig. 2) and by lacto phenol cotton blue staining, fungi were found to be as Cladosporium spp. and Aspergillius spp. Brown coloured precipitate development varied from organism to organism. Sagar Desai [8], isolated and characterized the laccase from Enterobacter spp. Gochev et al, [1] isolated 4 laccase producing Trichoderma spp. from soil sample, while Shraddha et al., [5] reported laccase production, from S. lavendulae, S.cyaneus, and Marinomonas mediterranea. Vladimir et al., [15] studied physiological regulation of laccase and manganese peroxidase production from white rot basidomycetes.

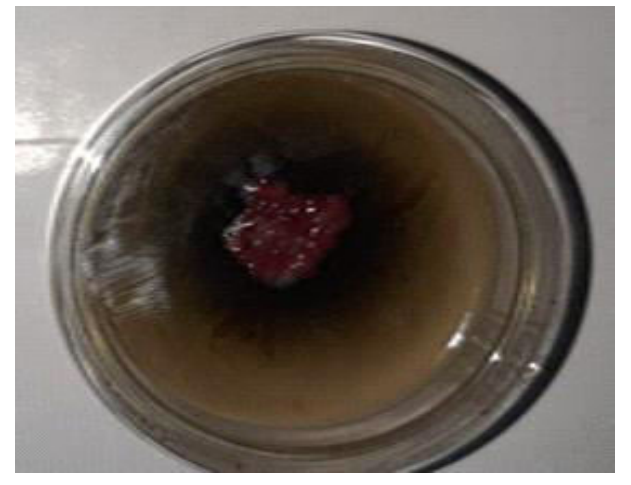

Fig. 1: Zone of Brown Colour due to laccase activity

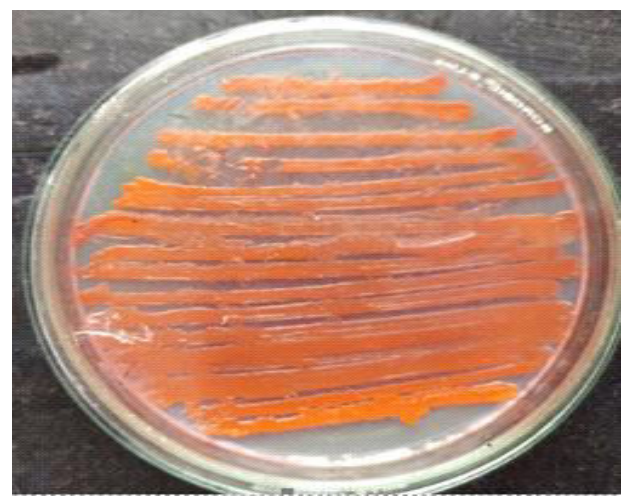

Fig. 2: Klebsiella Oxytoca 


\subsection{Laccase Assay}

After three days of incubation, supernatant obtained was subjected to laccase assay by using tannic acid as a substrate. Out of twenty-six isolates, three isolates showed highest laccase activity. The isolate Erwinia chrysanthemi produce $680 \mathrm{U} / \mathrm{ml}$, Pseudomonas aeruginosa $720 \mathrm{U} / \mathrm{ml}$, Klebsiella Oxytoca $980 \mathrm{U} / \mathrm{ml}$. showed laccase production after three days of incubation at $37^{\circ} \mathrm{C}$. Fungal isolates Cladosporium spp. and two Aspergillus spp. produced laccase 676 \& $719 \mathrm{U} / \mathrm{ml}$, respectively. Klebsiella Oxytoca showed maximum laccase activity i.e.980 U/L, B. subtilis (MTCC 2414) laccase showed maximum activity $(267 \pm 2.64 \mathrm{U} / \mathrm{mL})$ after $96 \mathrm{~h} \mathrm{[16],}$ while Pseudomonas putida (MTCC 7525) produced $(94.10 \mathrm{U} / \mathrm{ml})$ at $30^{\circ} \mathrm{C}$ and $\mathrm{pH} 8$ after $108 \mathrm{~h}$ incubation [10]. In the present study, isolate showed efficient laccase production than the earlier reports cited. The most efficient reproducible result was shown by Klebsiella oxytoca, hence for further optimization study Klebsiella Oxytoca was used.

\subsection{Optimization parameters for laccase activity}

Optimization studies include effect of $\mathrm{pH}$, temperature, substrate and incubation period on laccase activity. All the tests were run in triplicates. The effect of $\mathrm{pH}$ on laccase activity was studied at $\mathrm{pH}$ range of 4.5 to 8 , in present study. Laccase from Klebsiella Oxytoca showed laccase activity at all $\mathrm{pH}$, optimum laccase activity was at $\mathrm{pH} 7.5(978 \mathrm{U} / \mathrm{ml})$ and lowest activity at $\mathrm{pH} 4.5$ $(680 \mathrm{U} / \mathrm{ml})$ (Fig. 3) after $30 \mathrm{~min}$ of incubation, which indicate laccase activity was present in the slightly alkaline medium. Similar result was shown by Ambrin et al., [3] in their work, P. ostreatus showed laccase activity over a wide range of $\mathrm{pH} 5-11$. Highest laccase activity of $P$. putida was found at $\mathrm{pH} 8$ within $96 \mathrm{~h}$ at $40^{\circ} \mathrm{C}$ [10]. Temperature is a parameter which is important for enzyme stability. Laccase shows highest activity at $30^{\circ} \mathrm{C}(980 \mathrm{U} / \mathrm{ml})($ Fig.4) and lowest at the $15^{\circ} \mathrm{C} \mathrm{(193U/ml)} \mathrm{(Fig.4).}$

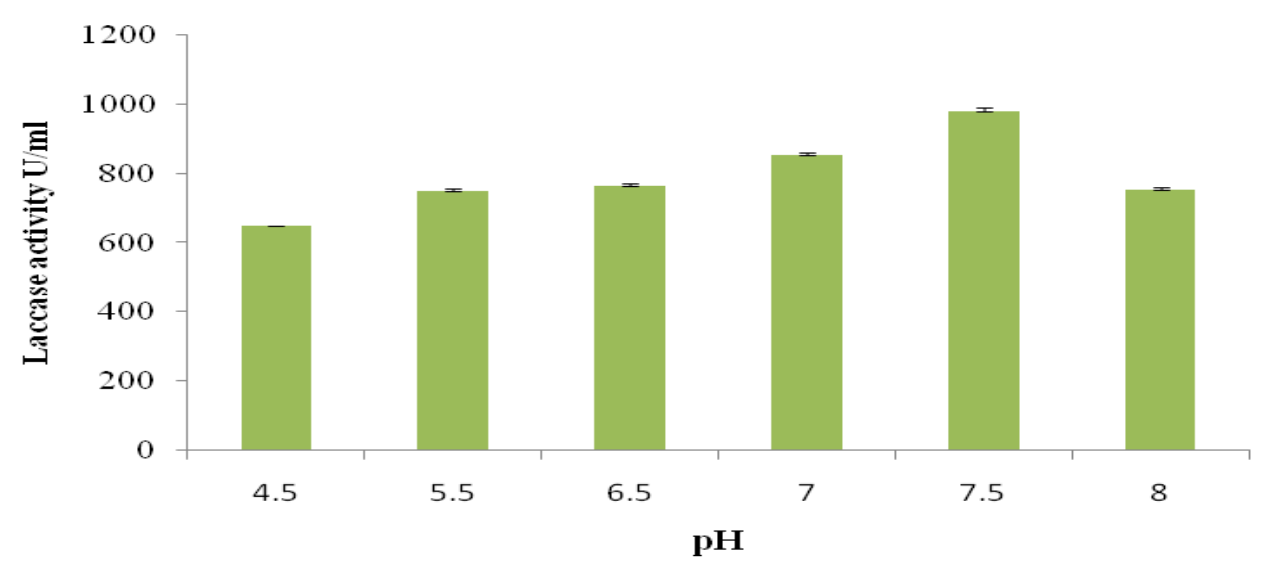

Fig. 3: Effect of $\mathrm{pH}$ on Laccase activity

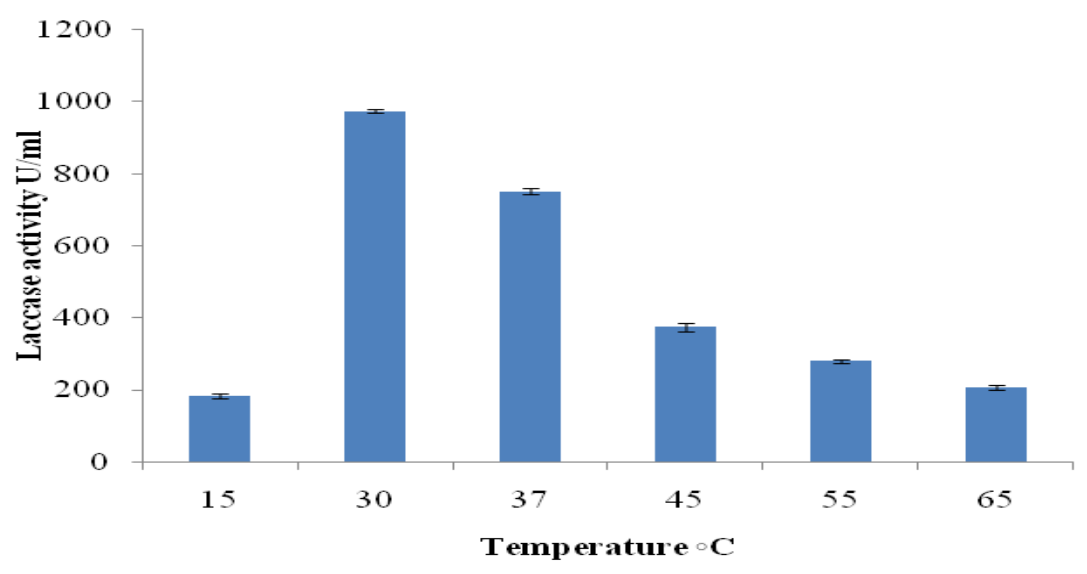

Fig. 4: Effect of temperature on Laccase activity 
Sagar Desai [8] observed maximum laccase production at $30^{\circ} \mathrm{C}$ temperature by Enterobacter spp. while Ambrin et al, [3] in his study reported that laccase from $P$. ostreatus have highest laccase activity at $50^{\circ} \mathrm{C}$.

The effect of substrate concentration on laccase production using B. subtilis (MTCC 2414) revealed that rice bran and wheat bran showed the maximum enzyme activity of $134.8 \pm 4.75 \mathrm{U} / \mathrm{mL}$ and $117.6 \pm 4.23 \mathrm{U} / \mathrm{mL}$, respectively [16].
In the incubation parameter, laccase was subjected to a different incubation period, maximum laccase activity was shown by Klebsiella Oxytoca at $30 \mathrm{~min}(960 \mathrm{U} / \mathrm{ml})$ (Fig.6) while laccase from Bacillus subtilis (MTCC 2414) showed maximum enzyme activity $(267 \pm 2.64 \mathrm{U} / \mathrm{mL})$ at $96 \mathrm{~h} \mathrm{[16].}$

All the parameters were studied in triplicate (Values are mean $\pm S D$ of three independent determinations).

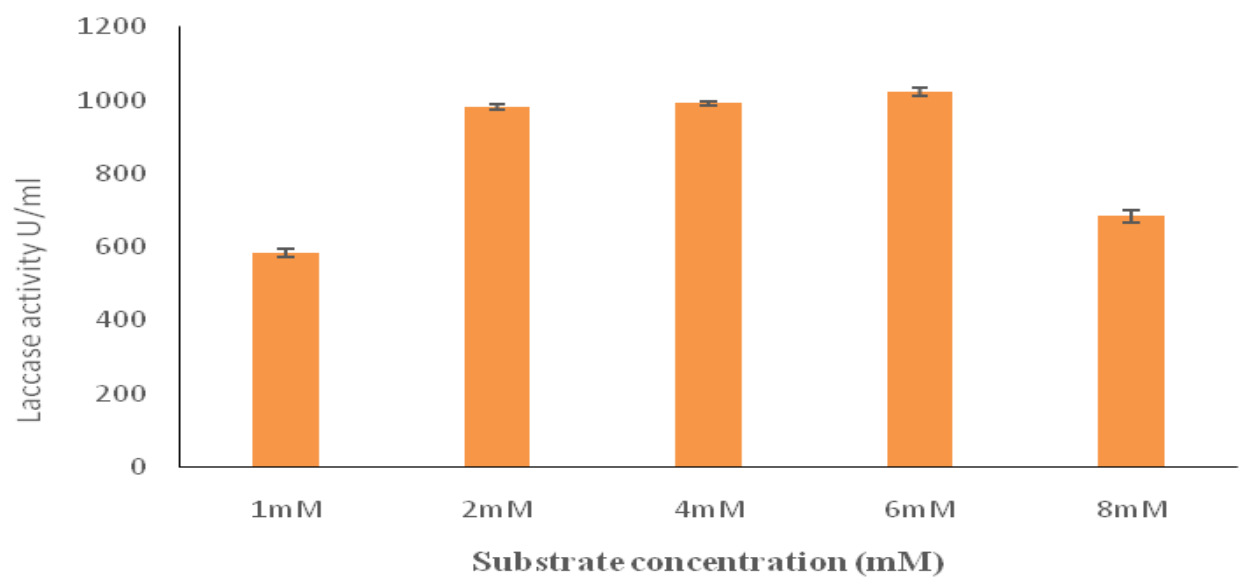

Fig. 5: Effect of substrate concentration on Laccase activity

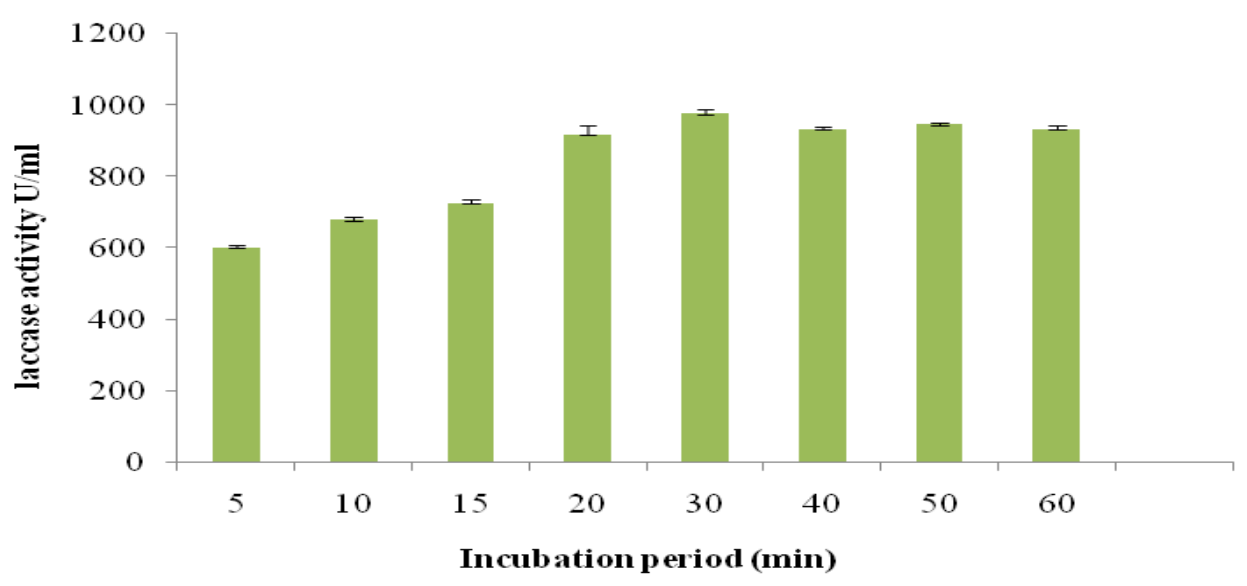

Fig. 6: Effect of incubation period on laccase activity

\subsection{Effect of metal ions and organic solvent}

The laccase activity was strongly inhibited by PMSF, which are well-known inhibitors of serine proteases. This suggested that a serine was involved in the catalytic activity [17]. In the presence of Cysteine, $\mathrm{MnSO}_{4}$ and $\mathrm{CuSO}_{4}$ laccase activity was enhanced 40\%, 135\%, 119\% respectively, while DMSO, $\mathrm{ZnSO}_{4}$, act as potent inhibitors, inhibiting 94\% and $95 \%$ activity, respectively. Some of some metal ions show negligible effect on laccase activity such as $\mathrm{HgCl}_{2}$, $\mathrm{Na}_{2} \mathrm{SO}_{4}$ (Fig. 7). Kuddus et al., [10] reported that $\mathrm{Hg}^{2+}$ ion show inhibitory effect at $10 \mathrm{mM}$ conc. retaining $27 \%$ activity while $\mathrm{pCMB}$ show complete inhibition at $10 \mathrm{mM}$. Metal ion $\mathrm{CuSO}_{4}$ enhanced maximum laccase activity of $141.4 \pm 6.64 \mathrm{U} / \mathrm{mL}$ followed by $\mathrm{FeSO}_{4}$ $(123.5 \pm 4.59 \mathrm{U} / \mathrm{mL})$. But, $\mathrm{MgSO}_{4}, \mathrm{CuCl}_{2}$, and $\mathrm{HgCl}_{2}$ were found to inhibit the laccase activity to a greater extent [16]. 


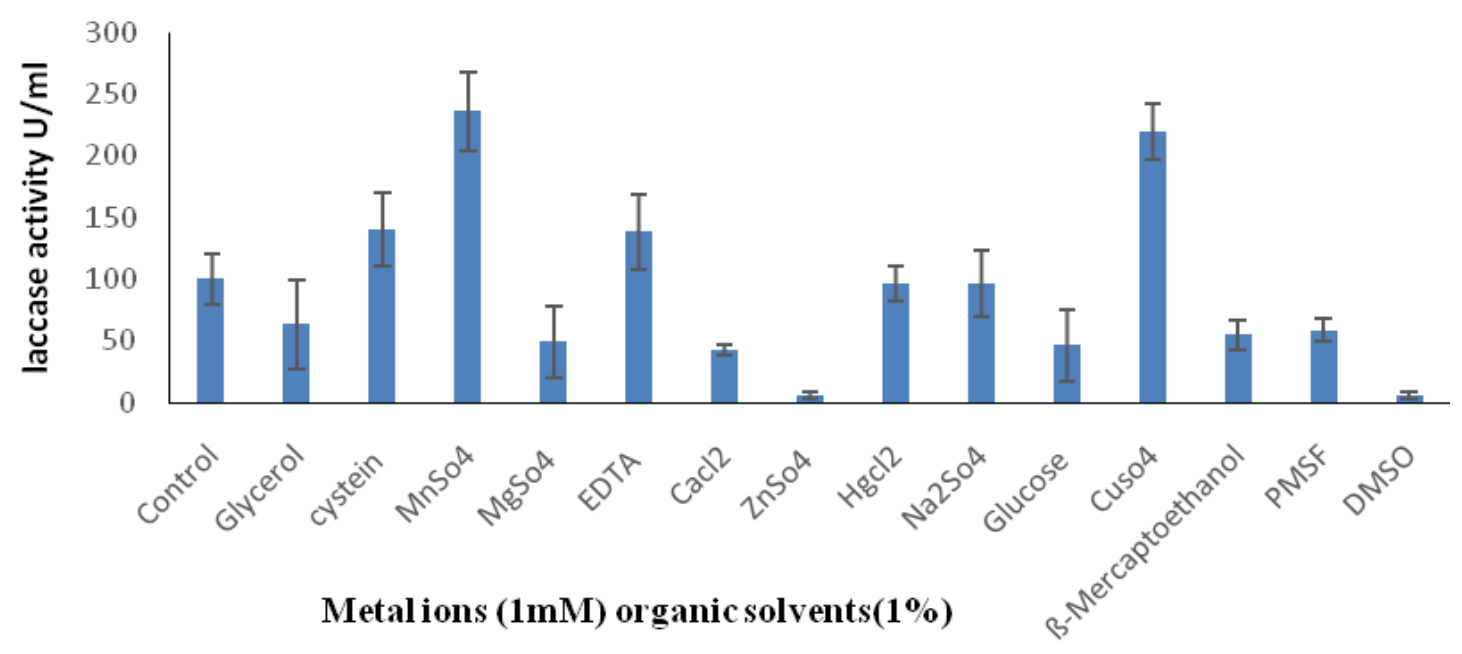

Fig. 7: Effect of metal ions and organic solvent on laccase activity

\subsection{Immobilization of laccase}

Laccase immobilization was done by the sodium alginate method (Fig. 5). After immobilization, laccase activity was found to be $784 \pm 12 \mathrm{U} / \mathrm{ml}$ which was found to be reduced as compared to the free enzyme 976 \pm 10 $\mathrm{U} / \mathrm{ml}$. This immobilized laccase was used in the dye degradation, silver nano particle synthesis, same was done by Zabin et al., [18], in their work they used calcium alginate beads, copper alginate beads, calcium alginate-chitosan beads and sol-gel matrix.

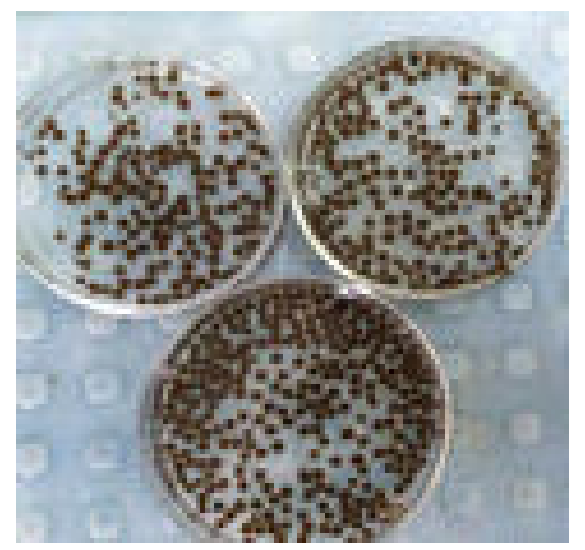

Fig. 8: Immobilized Enzyme

\subsection{Dye Degradation}

Dye degradation was observed by visual observation. Degradation of dye was carried out by crude extract, partially purified and immobilized laccase. In the present study, partially purified laccase from Klebsiella Oxytoca showed maximum degradation activity as compared to others. The best degradation by laccase was shown against the Crystal violet and Neutral red (Fig. 9). The dye degradation was clearly seen after incubation period and the optical density also decreases with respect to the incubation periods (Fig.10). 60\% crystal violet, $88 \%$ neutral red were degraded after 24 hrs . (First day), as incubation increases degradation was found to be increasing and after three days of incubation 94\% and 97\% dyes degraded respectively (Fig.10). Decolorization of dye (Bromophenol Blue, Congo red, Brilliant green, Crystal violet) and effluents (Paper effluent A, Paper effluent B and Textile effluent) by using laccase isolated from P. putida, [10]. Similarly, dye degradation by using laccase extracted from Pleurotus Ostreatus was done on 2 dyes Red F3B, T Blue G [3].

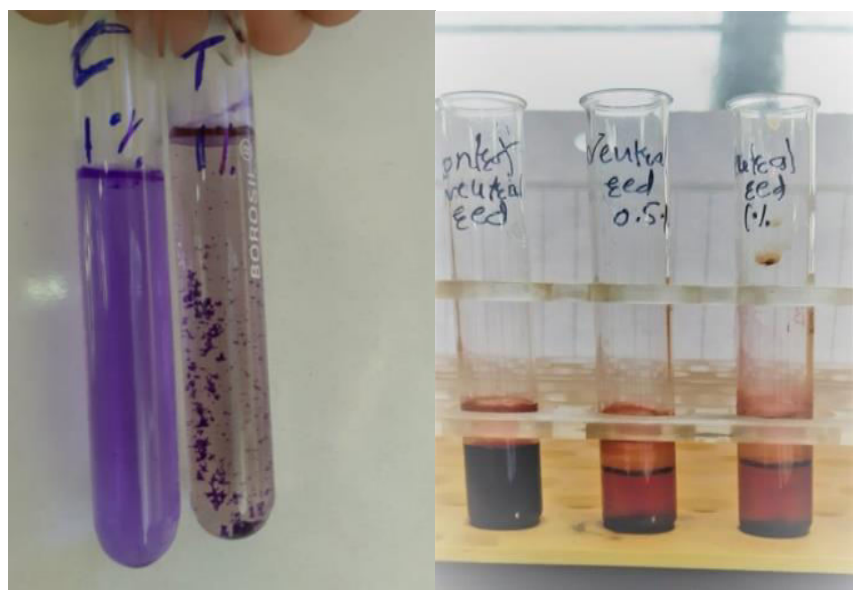

Fig. 9: Crystal violet and Neutral red degradation by laccase 


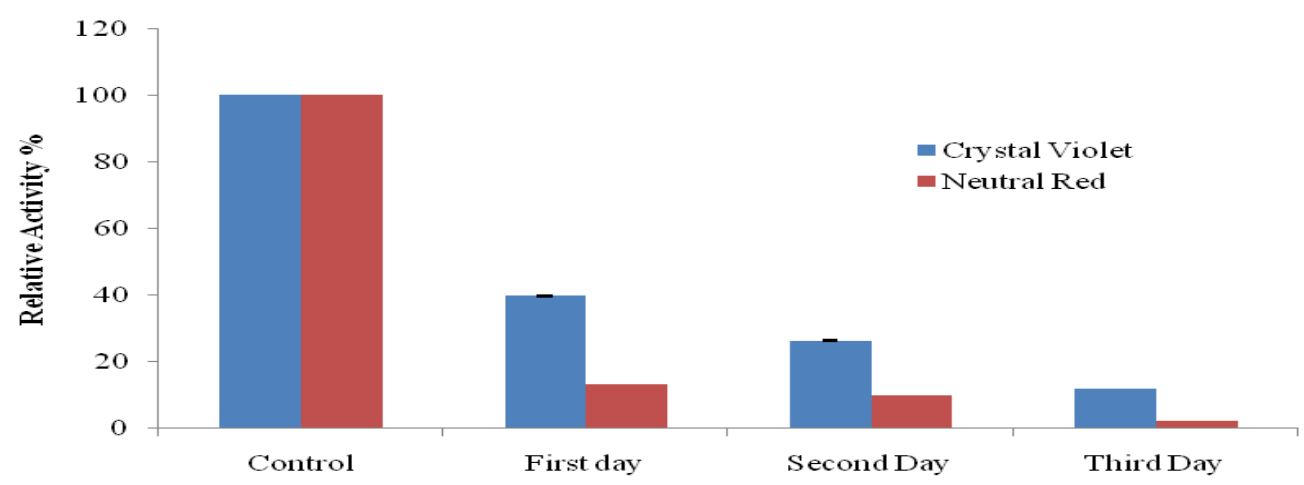

Fig. 10: Dye degradation by Laccase

\subsection{Meat Tenderization by laccase}

The water holding capacity (WHC) of meat is very important since physical properties such as colour, texture and firmness are partially dependent on the WHC. The water-holding capacity of the meat treated with various concentrations of laccase was calculated using the formula (Table 1) [12]. As compared to control, WHC capacity was found to be increased in presence of laccase. $1 \%$ the concentration of laccase showed highest WHC.

\subsection{Silver nanoparticle synthesis}

On adding, 4-5 immobilized laccase to the $1 \mathrm{mM}$ of silver nitrate solution, color of reaction mixture was found to be changed from colorless to reddish brown after an incubation of $2 \mathrm{hr}$. at $75^{\circ} \mathrm{C}$ indicates the enzymosynthesis of silver nanoparticles. Biosynthesis of silver nanoparticles was confirmed by UV-Vis spectra, showing the highest absorption peak at $410 \mathrm{~nm}$ and further used as an antibacterial agent against $S$. aureus, $S$. typhi, Agrobacterium tumefaciens, E. coli, Pseudomonas. Nelson et al., [19] in their work reported same production of silver nanoparticle using laccase from Trametes versicolor and characterized the nanoparticle by UV-Visible spectra in the range of $440-600 \mathrm{~nm}$ and XRD.

\subsection{Antibacterial activity}

Antibacterial activity of laccase and biosynthesized silver nanoparticles was tested against $S$. aureus $S$. typhi, Agrobacterium tumefaciens, E. coli, Pseudomonas, by agar well diffusion method. Laccase was significantly shown to have antibacterial activity against bacterial isolates $S$. aureus, S. typhi, Agrobacterium tumefaciens observed by the clear zone of inhibition which ranges from $17 \mathrm{~nm}$ to 24 mm Highest zone of inhibition was $24 \mathrm{~mm}$ which was against Agrobacterium and lowest against the E.coli $(17 \mathrm{~mm})$, while Agbaje et al., [20] reported that, the AgNPs showed selective antimicrobial activities against the ten clinical bacterial isolates tested. AgNPs synthesized induced a maximum inhibitory zone of $20 \mathrm{~mm}$ at a concentration of $141 \mu \mathrm{g} / \mathrm{ml}$ for AgNPs. Therefore, the appreciable antibacterial property demonstrated by the biosynthesized AgNPs.

Table 1: Meat tenderization

\begin{tabular}{cccc}
\hline $\begin{array}{c}\text { Samples } \\
\text { concentration) }\end{array}$ & $\begin{array}{c}\text { Initial } \\
\text { volume } \\
(\mathrm{ml})\end{array}$ & $\begin{array}{c}\text { Volume of } \\
\text { supernatant } \\
(\mathrm{ml})\end{array}$ & $\begin{array}{c}\text { Water } \\
\text { holding } \\
\text { capacity }(\%)\end{array}$ \\
\hline Control & 7.5 & 5.4 & 28 \\
\hline $1 \%$ & 7.5 & 4.3 & 42 \\
\hline $2 \%$ & 7.5 & 4.5 & 40 \\
\hline $3 \%$ & 7.5 & 4.7 & 37 \\
\hline $4 \%$ & 7.5 & 4.8 & 36 \\
\hline
\end{tabular}

\section{CONCLUSION}

In the present study, purified enzyme from Klebsiella Oxytoca using Tannic acid as substrate showed maximum laccase activity $(980 \mathrm{U} / \mathrm{ml})$ and stability at temperature $30^{\circ} \mathrm{C}, \mathrm{pH} 7.6$, and $6 \mathrm{mM}$ substrate concentration in 30 min incubation period. Partially purified laccase efficiently degraded $94 \%$ of crystal violet and $97 \%$ of neutral red was degraded after 3 days of incubation at $37^{\circ} \mathrm{C}$. Silver nanoparticles were also enzymosynthesized. It also has proficient antibacterial activity against S. aureus, S. typhi, and Agrobacterium tumifaciens ranging from $17 \mathrm{~mm}-24 \mathrm{~mm}$ and can be effectively used in meat tenderization. To the best of our knowledge, this is the first report on bacteria Klebsiella Oxytoca producing laccase and its use for decolorization of synthetic dyes. 
Therefore, this strain can be used to decolorize and detoxify the industrial effluents and help in wastewater treatment.

\section{ACKNOWLEDGEMENTS}

We wish to express our deep sense of gratitude to Principal Dr. P.V. Ashtekar Sir, Shivchhatrapati College, Aurangabad for providing laboratory facilities to carry on our work.

\section{Conflict of interest}

None declared

\section{REFERENCES}

1. Gochev V, Krastanov A. Bulg. J. Agric. Sci., 2007; 13:171-176.

2. Couto S, Herrera J. J. biotechadv., 2006; 24(5):500-513.

3. Babu AF. Int J Waste Resour, 2016; 6:199.

4. Kunamneni A, Ballesteros A, Plou F, Alcalde M. Comm.Cur. Res. and Edu. Topics and Tre. in Appli. Micro., 2007; 233-245.

5. Shraddha, Shekher R, Sehgal S, Kamthania M, Kumar A. SAGE-Hindawi, 2011; Article ID 217861, 11 pages doi:10.4061/2011/217861.

6. Desai S, Tennali G, Channur N, Anup A, et al. Biotechnol. Bioinf. Bioeng, 2011;1(4):543-549.

7. Jogdand K, Surywanshi D, Munde T, Kate S.
IAETSD Jou. Adv. Reas. Appl. Sci, 2018; 5(3):70-82.

8. Desai S. Biosci. Dis, 2017; 8(3):567-573.

9. Jayaraman J. Lab. manual in Biochem. 2, New Age International limited Publishers, New Delhi, 2011.

10. Kuddus M, Joseph B, Ramteke P, Biocat.and Agri. Biotech, 2013; 2:333-338.

11. Mogharabi M, Koopaei N, Bozorgi-Koushalshahi M, Nafissi-Varcheh N, et al., Bioing. Chem. and App, 2018; 2012: Article ID 823830.

12. Manohar J, Gayathri R, Vishnupriya V. Int.J. Pharm. Sci. Res, 2016; 39(1):81-85.

13. Liangwei D, Xian L, Feng J. J Nanopart Res, 2010; 13:921-930.

14. Christie S, Shanmugam S. Int. J. of Plant, Animal and Environ. Sci., 2012; 2:143-148.

15. Vladimir E, Kachlishvili E, Journal of Biotechnology, 2009; 144:37-42.

16. Narayanan P, Muthukumarasamy, Beenie J, Antony J, Murugan S. Biochemistry Research International 2015, Article ID 765190.

17. Shivkumar T, Ramasubramanian V, Arasu V. Insight Bacteriol, 2012; 1:1-6.

18. Zabin K, Bagewadi, Sikandar I, Mulla, et al., Jou. of Gen. Engin. and Biotech, 2017; 1-12.

19. Durán N, Cuevas R, Cordi L, Rubilar O, et al. Springer Plus, 2014; 3:645

20. Lateef A, Adeeyo A. Not Sci Biol, 2015; 7(4):405411. 